\title{
Antioxidant Capacity and Protective Effect of Aqueous and Hydroalcoholic Extracts of Senecio rhizomatus Rusby "Llancahuasi" on Erythrocytes Subjected to Oxidative Stress
}

\author{
Justil-Guerrero Hugo Jesús ${ }^{1} *$, Chávez-Flores Juana Elvira', Cárdenas-Orihuela Robert Armando', Ramos- \\ Jaco Antonio Guillermo', Ñañez-del-Pino Daniel', Vásquez-Quispe Ángel David', Rojas-Cardenas Nathalie \\ Felicita', Fernández-Flores Nélber'
}

Justil-Guerrero Hugo Jesús',*, Chávez-Flores Juana Elvira', Cárdenas-Orihuela Robert Armando', Ramos-Jaco Antonio Guillermo', Ñañez-del-Pino Daniel ${ }^{1}$, Vásquez-Quispe Ángel David', Rojas-Cardenas Nathalie Felicita ${ }^{1}$, Fernández-Flores Nélber ${ }^{1}$

${ }^{1}$ Facultad de Farmacia y Bioquímica, Universidad Norbert Wiener, PERÚ.

\section{Correspondence}

Justil-Guerrero Hugo Jesús

Facultad de Farmacia y Bioquímica, Universidad Norbert Wiener, PERÚ.

E-mail: hugo.justil@uwiener.edu.pe History

- Submission Date: 26-10-2020;

- Review completed: 17-11-2020;

- Accepted Date: 01-12-2020.

DOI : 10.5530/pj.2021.13.65

Article Available online http://www.phcogj.com/v13/i2

\section{Copyright}

(C) 2021 Phcogj.Com. This is an openaccess article distributed under the term of the Creative Commons Attribution 4.0 International license.

\begin{abstract}
Objective. To evaluate the antioxidant capacity and protective effect of aqueous and hydroalcoholic extracts of Senecio rhizomatus Rusby in rat erythrocytes subjected to oxidative stress with hydrogen peroxide $\left(\mathrm{H}_{2} \mathrm{O}_{2}\right)$. Methodology. This study used an experimental design. The extracts were obtained through maceration with $96^{\circ}$ ethanol (SeR96), $70^{\circ}$ ethanol (SeR70), 50 ethanol (SeR50) and through infused water (SeRAc). Secondary metabolites were identified through colorimetric reactions and precipitation. In each extract, we could determine the capacity to eliminate 2,2-diphenyl-1-picrylhydrazyl radical (DPPH), the reduction of ferric ion and the total polyphenol content. In addition, the activity on the plasma membrane redox system (PMRS) was evaluated in each extract. The protection against oxidative stress in erythrocytes was evaluated by determining the content of reduced glutathione (GSH) and malondialdehyde (MDA). Results. Alkaloids, flavonoids, phenolic compounds, sesquiterpene lactones and sugars were identified in all the extracts. The total polyphenols content showed a correlation with the reduction of ferric ion $(r=0.885)$ and with DPPH radicals elimination ( $r$ $=-0.899$ ), where the one with the highest antioxidant capacity was SeR50. Thus, the SeR50 (all concentrations) and SeR70 (100 $\mathrm{gg} / \mathrm{mL}$ concentration) significantly increased the PMRS activity compared to the control group. After inducing oxidative stress in erythrocytes, all the extracts maintained the GSH level and inhibited MDA formation significantly compared to the $\mathrm{H}_{2} \mathrm{O}_{2}$ group. Conclusion. The antioxidant capacity of hydroalcoholic extracts $\left(96^{\circ}, 70^{\circ}, 50^{\circ}\right)$ and aqueous infusion of Senecio rhizomatus Rusby is related to the content of polyphenols. They increase the plasma membrane redox system activity in rat erythrocytes and protect them from oxidative stress induced with $\mathrm{H}_{2} \mathrm{O}_{2}$ showing an increase in the concentration of reduced glutathione and a decrease in malondialdehyde.
\end{abstract}

Key words: Antioxidant, Reactive oxygen species, Plasma membrane redox system, Reduced glutathione, Lipoperoxidation.

\section{INTRODUCTION}

Oxidative stress is the imbalance between oxidants and antioxidants, which cause cell damage. ${ }^{1}$ It is considered the main cause of noncommunicable diseases such as diabetes which, through hyperglycemia, generates complications such as hyperlipidemia and hypertension, damaging multiple organs. ${ }^{2,3}$ In addition, it causes endothelial dysfunction, which generates cardiovascular problems such as atherosclerosis, ${ }^{4}$ neurodegeneration, immunosuppression and aging. ${ }^{5,6}$ The potential role of free radicals, reactive oxygen species (ROS) and antioxidants in the etiology of chronic diseases has stimulated an increase in research over the last few years. ${ }^{7}$ These diseases can be prevented by healthy diets and the consumption of antioxidants. ${ }^{8}$ Thus, vegetable species, which are traditionally used by the population in diverse forms of administration, are a potential source of prevention of noncommunicable diseases.
In mammalian systems, erythrocytes have enzymatic and non-enzymatic antioxidant defenses, such as glutathione $(\mathrm{GSH})$ vitamin $\mathrm{C}$ and vitamin $\mathrm{E}$, to recognize ROS levels and limit the damage they produce. ${ }^{9}$ In addition, these cells have a system to transfer electrons in the membranes known as the plasma membrane redox system (PMRS), which is an electron transport chain in the plasma membrane by which the cells oxidize the electron donors, mainly $\mathrm{NADH}$ or $\mathrm{NADPH}$, and transfer the resulting electrons to the extracellular acceptors to protect them from free radicals. These defenses decrease with age, as well as with chronic diseases where PRMS is altered in erythrocytes. ${ }^{10}$ During these conditions, some reports show that the decrease in antioxidant defenses may increase with antioxidant supplementation. ${ }^{11,12}$ The PMRS system contains proteins that are electron donors, electron transporters, extracellular electron acceptors and oxidoreductase enzymes. ${ }^{13}$ Lately, antioxidants have been studied in numerous epidemiological research that had related their consumption to the reduction

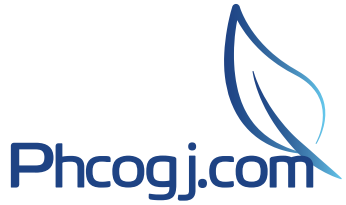

Cite this article: Justil-Guerrero Hugo J, Chávez-Flores Juana E, Cárdenas-Orihuela Robert A, Ramos-Jaco Antonio G, Ñañez-del-Pino Daniel, Vásquez-Quispe Ángel D, et al. Antioxidant Capacity and Protective Effect of Aqueous and Hydroalcoholic Extracts of Senecio rhizomatus Rusby "Llancahuasi" on Erythrocytes Subjected to Oxidative Stress. Pharmacog J. 2021;13(2): 516-27. 
of the appearance of diseases related to oxidative damage, hence, the interest has been focused mainly on the use of natural antioxidants for the improvement of human health. ${ }^{14}$

Polyphenols are effective against free radicals, since they strengthen the endogenous antioxidant system, reducing lipid oxidation, protein oxidation and mRNA damage, preventing inflammatory processes that are aggravating factors in noncommunicable diseases such as cardiovascular, degenerative diseases of the central nervous system, as well as respiratory diseases, cancer and diabetes..$^{15}$ Senecio rhizomatus Ruby belongs to the herbaceous stratum and grows in the Andes of Bolivia and Peru, specifically in La Libertad, Ancash, Junín, Huancavelica, Lima, Apurimac, Arequipa, Cuzco and Puno between 3600 and 5000 meters above sea level between the rock crevices and snow covered soils. In addition, this species is used as a medicine with the name "llancahuasha", "ticllahuasha", "llancahuasi". ${ }^{16,17}$ One traditional form to use it is as a type of plaster for skin application when having external wounds; another form is in maceration and infusions administrated orally when having respiratory tract conditions. ${ }^{18}$ In the ethanolic and aqueous extracts of this species, active metabolites such as tannins, flavonoids, saponins, steroids, triterpenoids and alkaloids have been identified. ${ }^{18,19}$ However, the antioxidant capacity is still unknown, as well as the in vitro evaluation of its action on cell membrane redox systems and the protection against oxidative stress.

The redox system in mammalian erythrocytes stands out for being part of the most abundant cells in blood exposed to constant oxidation caused by free radicals due to the presence of hemoglobin, which is the main source of maintenance of the redox system since they do not have mitochondria. ${ }^{20}$

Therefore, the objective of this study was to evaluate the antioxidant capacity of the aqueous (SeRAc), $50^{\circ}$ ethanolic (SeR50) and $96^{\circ}$ ethanolic (SeR96) extracts of Senecio rhizomatus Rusbi as well as the protective effect on the oxidative stress induced in rat erythrocytes with hydrogen peroxide $\left(\mathrm{H}_{2} \mathrm{O}_{2}\right)$, evaluating indicators of the activity of the plasma membrane redox system (PMRS), reduced glutathione content (GSH) and malondialdehyde (MDA).

\section{MATERIALS AND METHODS}

The design of the present study was experimental and was developed following the "ARRIVE" guidelines for experimental research with animals. It was also approved by the Institutional Research Ethics Committee of the Norbert Wiener Private University with file No. 0052019.

Senecio rhizomatus Rusby and the packed red blood cells (PRBC) obtained through cardiac puncture in rats were considered the population. The units of analysis were the types of extracts and erythrocytes respectively. The sample and replicates are described below:

Collection of the plant species, its taxonomic classification and how the extracts of Senecio rhizomatus Rusby were obtained

The plant species was collected in Parco Villanueva, in the district of Acostambo, province of Tayacaja, department of Huancavelica, between the months of May and June 2019. The taxonomic classification was done at the Natural History Museum of the National University of San Marcos (Universidad Nacional Mayor de San Marcos) according to the Cronquist System of Classification (1988). In order to obtain the dry extract, the fresh species was dehydrated in an oven at a controlled temperature $\left(40^{\circ} \mathrm{C} \pm 2^{\circ} \mathrm{C}\right)$, then the plant was pulverized and the hydroalcoholic and aqueous extracts were obtained, as described by Casado et al. ${ }^{21}$ The hydroalcoholic extracts $\left(96^{\circ}, 70^{\circ}, 50^{\circ}\right)$ were macerated for seven days and the aqueous ones were put in infusion for 30 minutes in a 1:10 ratio (extract: solvent). Next, with the help of a rotary evaporator, the extract was concentrated and dried in an oven at $40 \pm 2^{\circ} \mathrm{C}$ to obtain the dry extracts.

\section{Qualitative phytochemical profile analysis}

For the identification of metabolites, the method proposed by Lock ${ }^{22}$ was used. It allowed the identification of different compounds through different tests of color change and precipitation. In addition, fractionation methods were designed to guide the phytochemical studies for a better result.

\section{Determining the total polyphenol content}

It was carried out according to the Quispe-Mendoza et al. method ${ }^{23}$ with some modifications. Gallic acid (GA) at concentrations of 1, 2, 3,4 and $5 \mu \mathrm{g} / \mathrm{mL}$ was used as reference standard to make a calibration curve. For the analysis, $25 \mathrm{mg}$ of the sample were weighed; then, it was dissolved in $2.5 \mathrm{~mL}$ of methanol. In addition, we diluted it with distilled $\mathrm{H}_{2} \mathrm{O}$ to obtain concentrations of $100 \mu \mathrm{g} / \mathrm{mL}$. From the new dilution, 500 $\mu \mathrm{L}$ were taken and $250 \mu \mathrm{L}$ of Folin Cicalteu reagent were added $(1,2$ $\mathrm{N}$ ); then, it was shaken for 5 minutes and $1250 \mu \mathrm{L}$ of calcium carbonate was added. After 60 minutes, the absorbance was measured with a UVVIS spectrophotometer at $760 \mathrm{~nm}$. The results were expressed as $\mathrm{mg}$ of gallic acid equivalents in $1 \mathrm{~g}$ of a dry sample (mg GA/g).

Evaluation of the capacity to reduce 2,2-diphenyl-1picrylhydrazyl radical (DPPH)

The antioxidant capacity of the extract was based on the reduction of the DPPH radical, showing a decrease in the violet coloration according to the Umamaheswari et al..$^{24}$ method, where a $0.4 \mathrm{mM}$ solution of DPPH in pure methanol was prepared. Then, from this solution, 100 $\mu \mathrm{L}$ was added to the different types of extracts diluted to $200 \mu \mathrm{L} / \mathrm{mL}$ at a concentration. After slightly shaking, the solution was left to stand at room temperature protected from light for 30 minutes. Finally, the absorbance was measured at $517 \mathrm{~nm}$ using a microplate reader as a way of comparison to the antioxidant capacity of ascorbic acid.

\section{Determining the capacity to reduce ferric ion}

It was done according to the Benzi et al. ${ }^{25}$ method with some modifications. The method is based on the ferric iron reduction $\left(\mathrm{Fe}^{+3}\right)$ present in the FRAP reagent as well as in the ferrous form $\left(\mathrm{Fe}^{+2}\right)$ in the presence of antioxidants. The FRAP reagent was prepared on the same day of the assay by mixing acetic acid-sodium acetate buffer ( $\mathrm{pH} 3.6$ ), TPTZ (2,4,6-tri(2-pyridyl)-striazine) and $\mathrm{FeCl}_{3}$. The reductive capacity of the sample forms a blue coloration of intense proportionality due to the generation of ferrous-TPTZ complex. Twenty five mg of ascorbic acid was weighed, diluted in $2.5 \mathrm{~mL}$ of methanol and diluted with $\mathrm{H}_{2} \mathrm{O}$ until obtaining a solution of $100 \mu \mathrm{g} / \mathrm{mL}$. From this solution, $500 \mu \mathrm{L}$ were taken and $1.5 \mathrm{~mL}$ of FRAP solution was added. After leaving it to stand in the dark for 60 minutes, the absorbance was determined in a UV-VIS spectrophotometer at $593 \mathrm{~nm}$. The capacity to reduce ferric ion was expressed as mg equivalent of ascorbic acid (AA) in $1 \mathrm{~g}$ of dry sample (mg AA/g).

\section{Experimental animals and obtaining packed red blood cells (PRBC)}

Twelve 8-week old male Hotzman rats between 200 and 220 g. of body weight acquired from the National Institute of Health (NIH) were used. For the animals' maintenance and care during the study, the guidelines of the "Guide for the care and use of laboratory animals" ${ }^{\text {"26 }}$ were followed. The acclimatization was carried out one week before the beginning of the trial, 4 rats per $1200 \mathrm{~cm}^{2}$ cage were kept with water and food at will, the cleaning and disinfection of the cage was carried out twice a week, room temperature was kept at $22^{\circ} \mathrm{C} \pm 2{ }^{\circ} \mathrm{C}, 50 \%$ relative humidity and 12 hours of light and 12 hours of darkness. 
Blood was obtained in the morning on an empty stomach by means of cardiac puncture. Two $\mathrm{mL}$ of blood were extracted in heparinized tubes, it was immediately centrifuged at $1800 \times \mathrm{g}$ during 10 minutes, the plasma was eliminated leaving the PRBC which was washed 3 times with a phosphate buffered saline solution (PBS) $\mathrm{pH} 7,4$. Then it was diluted at $20 \%$ with PBS. From the PRBC, three groups were formed for the PMRS, MDA and GSH assays. Each group was subdivided into three subgroups for each extract of SeR96, SeR50 and SeRAc and $1 \mathrm{~mL}$ of PRBC sample for each type of extract were considered for the assay with the dilutions of $100,50,25$ and $12.5 \mu \mathrm{g} / \mathrm{mL}$. Likewise, samples of 1 $\mathrm{mL}$ were considered for the control and $\mathrm{H}_{2} \mathrm{O}_{2}$ groups.

\section{In Vitro Incubation of Erythrocytes with the extracts}

From each extract (SeR96, SeR70, SeR50 and SeRAc), dilutions of 100; 50; 25; and $12.5 \mu \mathrm{g} / \mathrm{mL}$ were obtained using PBS with $0.01 \%(\mathrm{w} / \mathrm{v})$ ascorbic acid in the final solution. For the control and $\mathrm{H}_{2} \mathrm{O}_{2}$ groups, $\mathrm{PBS}$ with $0.01 \%(\mathrm{w} / \mathrm{v})$ ascorbic acid was used for incubation. All dilutions were obtained in triplicate. To each dilution, $1 \mathrm{~mL}$ of PRBC was added and it was incubated for 30 minutes at $37^{\circ} \mathrm{C}$ with constant shaking; at the end of incubation, erythrocytes were washed three times. Finally, the new PRBC was used for PMRS, MDA and GSH activity assays.

\section{Determining the Plasma Membrane Redox System (PMRS) Activity}

The activity of the plasma membrane redox system was determined by quantifying the reduction of ferrocyanidine according to the Avron and Shavit method. ${ }^{27}$ First, $0.2 \mathrm{~mL}$ of PRBC was taken from the dilutions of the extracts and the control group which were suspended in PBS containing $5 \mathrm{mM}$ glucose and $1 \mathrm{mM}$ of freshly prepared potassium ferricyanidin until obtaining a final volume of $2 \mathrm{~mL}$. The suspension was incubated for 30 minutes at $37^{\circ} \mathrm{C}$ and then centrifuged at 1800 RPM. The supernatant was collected to determine the ferrocyanidine content using the 4,7-diphenyl-1,10-phena-nthroline disulfonic acid disodium salt and measured at an absorbance of $535 \mathrm{~nm}(\mathrm{e}=20,500$ $\left.\mathrm{M}^{-1} \cdot \mathrm{cm}^{-1}\right)$. The results were expressed in $\mu \mathrm{mol}$ of ferrocyanidine / $\mathrm{mL}$ of PRBC / 30 min.

\section{Inducing oxidative stress}

The oxidative stress was induced to the groups with extracts and to the $\mathrm{H}_{2} \mathrm{O}_{2}$ group, according to the method described by Stocks and Dormandy ${ }^{28}$, incubating $0.5 \mathrm{~mL}$ of PRBC with $0.5 \mathrm{~mL}$ of $\mathrm{H}_{2} \mathrm{O}_{2} 200$ mmol during 30 minutes with constant shaking. At the end of the incubation, it was shaken before using it for the determination of MDA and GSH.

\section{Determining the malondialdehyde (MDA) content}

For determining the MDA content in erythrocytes, the Esterbauer and Cheeseman ${ }^{29}$ method was used: $0.2 \mathrm{~mL}$ of packed red blood cells from the previous process were suspended in $3 \mathrm{~mL}$ of PBS containing 0.5 $\mathrm{mM}$ glucose. From the new suspension, $0.2 \mathrm{~mL}$ was taken and $1 \mathrm{~mL}$ of $20 \%$ trichloroacetic acid (TCA) was added, shaken and centrifuged at $2000 \mathrm{RPM}$. Then, we added $2 \mathrm{~mL}$ of $0.67 \%$ thiobarthybituric acid. After that, we boiled it for 20 minutes at above $90^{\circ} \mathrm{C}$ temperature, and then, it was cooled with ice. Finally, the absorbance was measured at $532 \mathrm{~nm}$. The MDA concentration was calculated using an extension coefficient $\left(\mathrm{e}=156000 \mathrm{M}^{-1} \cdot \mathrm{cm}^{-1}\right)$. The MDA concentration is expressed in nmol. $\mathrm{mL}^{-1}$ of the packed red blood cells.

\section{Determining the reduced glutathione level (GSH)}

The GSH content was determined following the Beutler and Sedlak et al. ${ }^{30,31}$ method. It is based on the reduction of $5.5^{1-}$ Dithiobis (2-nitrobenzoic acid) (DTNB) due to the sulfhydryl group (SH) to the yellow nitro mercaptobenzoic acid anion. We used $0.1 \mathrm{ml}$ of the sample and diluted it with $0.9 \mathrm{ml}$ of PBS. One $\mathrm{ml}$ of $20 \%$ trichloroacetic acid (TCA) was added and left to stand for 20 minutes before centrifugation at $3000 \mathrm{RPM}$ for 10 minutes. Then, $0.25 \mathrm{ml}$ of the supernatant was taken and added to $0.75 \mathrm{ml} \mathrm{PBS}$; subsequently, $2 \mathrm{ml}$ of $0.0006 \mathrm{M}$ of DTNB was added and incubated for 10 minutes. The absorbance was read at 412 $\mathrm{nm}$. The concentration was calculated using the extension coefficient $(\mathrm{e}$ $\left.=13100 \mathrm{M}^{-1} \cdot \mathrm{cm}^{-1}\right)$. The GSH concentration is expressed in $\mathrm{mg} / \mathrm{mL}$ of packed red blood cells.

\section{Data collection techniques, instruments, and procedures}

The techniques to determine the biochemical parameters (DPPH, MDA, GHS, PRMS) are based on chemical reactions with typical coloring where the absorbances were measured with UV-VIS spectrophotometer equipment, at different wavelengths according to each analytical technique. The obtained results were recorded in a virtual data collection sheet and then processed in their respective spreadsheets.

\section{Data processing and analysis}

The mean and standard deviation of each group was determined taking into account that the variables are quantitative. In the first stage, the homogeneity of variance was determined using the Shapiro Wilk's normality test. In the second stage, we used the ANOVA test to verify the variance. In the third stage, the Tukey test was applied to evaluate the difference between the groups. The correlation between the antioxidant capacity variables and the phenolic compounds was evaluated with the Pearson's test. All the analyses were evaluated with a significance level of $\mathrm{p}<0.05$ or $\mathrm{p}<0.01$. The data were processed through Excel software and SPSS Version 24

\section{RESULTS}

Taxonomic classification of the species and the obtaining of the hydroalcoholic extracts

The plant species was identified as Senecio rhizomatus Rusby, according to certificate No. 243-USM-2019 issued by the Natural History Museum of the National University of San Marcos. The obtained extracts were SeR 96, SeR70, SeR50 and SeRAc as shown in Figure 1, the performance was $23 \%, 37 \%, 48 \%$ and $46 \%$ respectively.

\section{Qualitative analysis of the phytochemical profile}

Alkaloids, flavonoids, phenolic compounds, sesquiterpene lactones and sugars were identified in all extracts. On the other hand, quinones, tannins, amino groups and reducing sugars were only in the SeR70, SeR50 and SeRAc extracts. Also, triterpenes and steroids were identified only in the SeR96, SeR70 and SeR50 extracts as summarized in Table 1.

\section{Antioxidant capacity of the extracts}

The hydroalcoholic $\left(96^{\circ}, 70^{\circ}, 50^{\circ}\right)$ and aqueous extracts which was proportional to the concentration in each extract (Figure 2). In addition, it was evidenced that the elimination expressed in IC50 was inversely proportional to the reduction of ferric ion, with a correlation of -0.903 with a $\mathrm{p}<0.01$ significance level. The extract with the best DPPH radical elimination and the highest ferric ion reduction was SeR50 (Table 2 and Figure 3).

\section{Polyphenol content}

The total polyphenols expressed in $\mathrm{mg} \mathrm{GA} / \mathrm{g}$ of dry extract was proportional to the elimination of ferric ion expressed in $\mathrm{mg} \mathrm{AA} / \mathrm{g}$ of dry extract and inversely proportional to the elimination of DPPH radical expressed in IC50, which had a correlation of 0.885 and -0.899 respectively with a significance level of $\mathrm{p}<0.01$. 


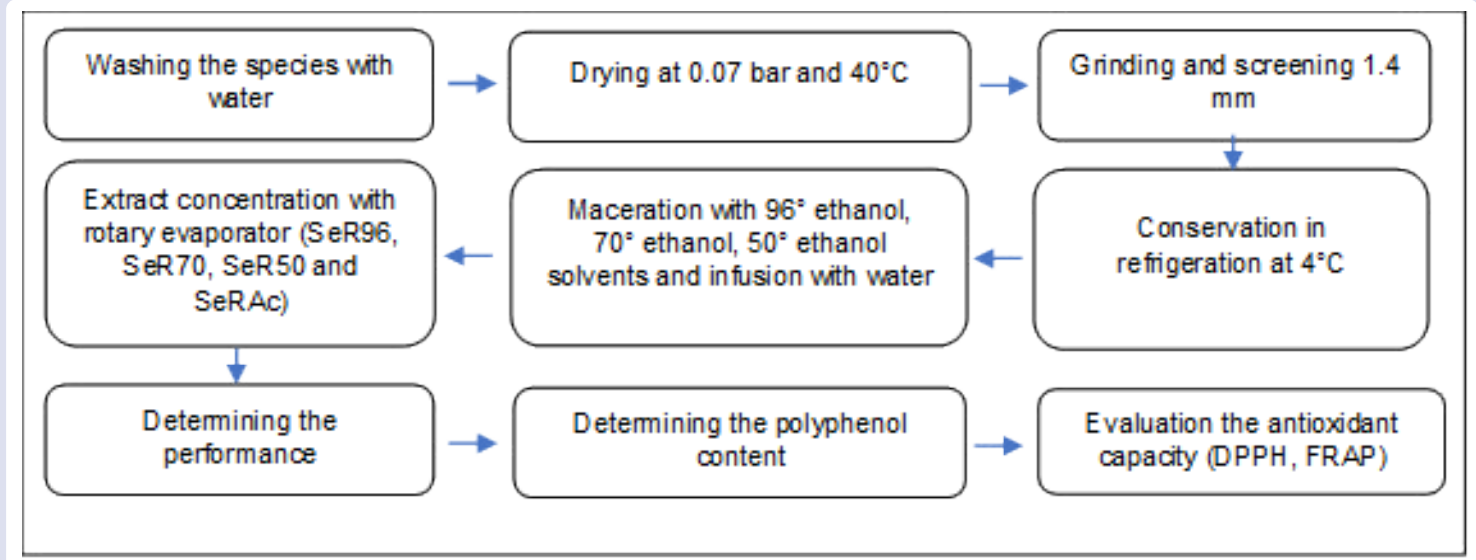

Figure 1: Flowchart of how the extracts of Senecio rhisomatus Rusby were obtained, SeR96: $96^{\circ}$ Ethanolic extract; SeR70: $70^{\circ}$ Ethanolic extract; SeR50: $50^{\circ}$ Ethanolic extract and SeRAc: Aqueous extract.

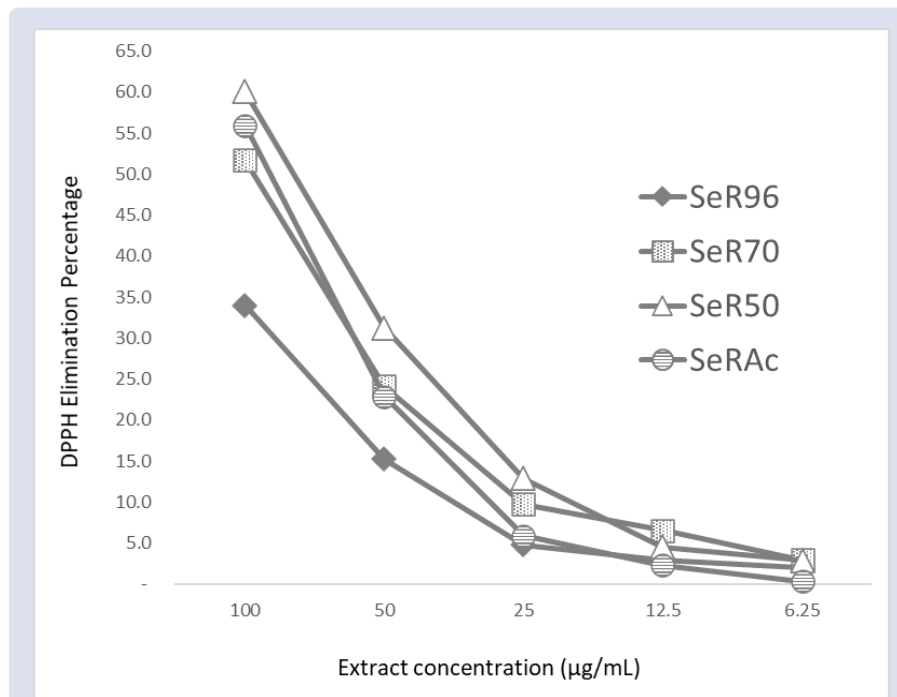

Figure 2: Percentage of the elimination of DPPH radical in SeR96, SeR70, SeR50, SeRAc extracts at concentrations of 100, 50, 25, 12.5 and $6.25 \mu \mathrm{g} /$ $\mathrm{mL}$; DPPH: 2,2-diphenyl-1-picrylhydrazyl.

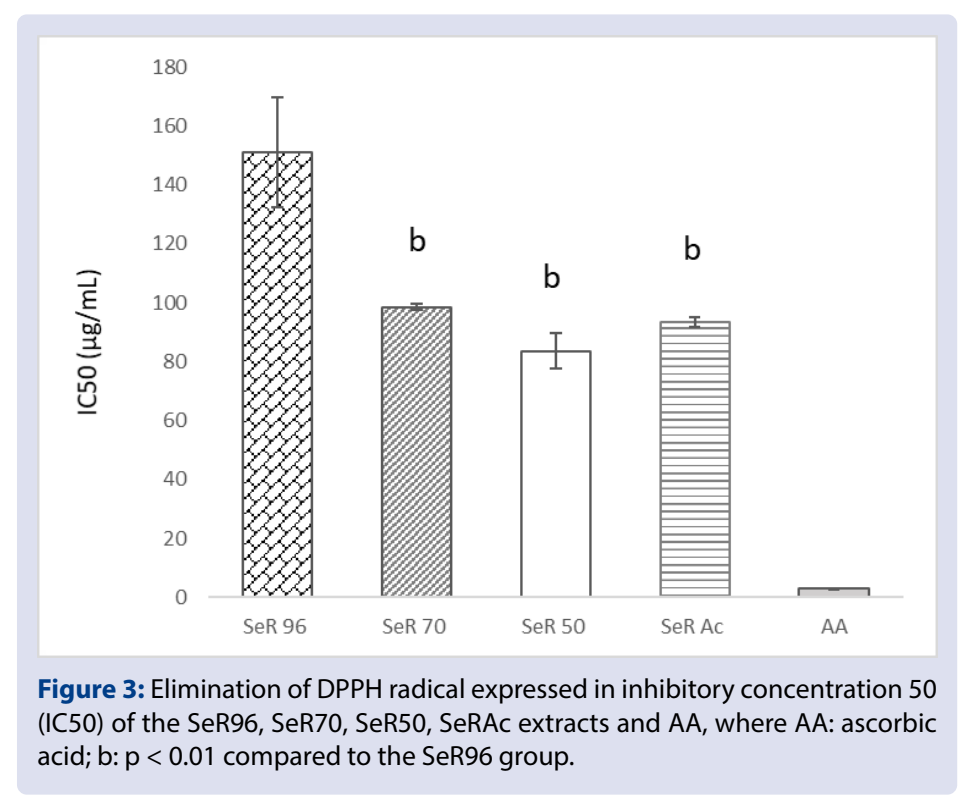


Table 1: Identification of phytochemical constituents of Senecio rhizomatus Rusby extracts.

\begin{tabular}{|c|c|c|c|c|c|}
\hline Active Metabolites & Reagents & SeR 96 & SeR 70 & SeR 50 & SeR Ac \\
\hline \multirow{3}{*}{ Alkaloids } & Mayer & + & + & + & + \\
\hline & Dragendorff & + & + & + & + \\
\hline & Wagner & + & + & + & + \\
\hline \multirow{2}{*}{ Flavonoids } & Shinoda & + & + & + & + \\
\hline & Aluminum trichloride $1 \%$ & + & + & + & + \\
\hline Quinone & Borntrager & - & + & + & + \\
\hline Phenolic compounds & Ferric trichloride $1 \%$ & + & + & + & + \\
\hline Saponins & Sample + water dest $1 \%$ & - & - & - & - \\
\hline Tannins & Gelatin & - & + & + & + \\
\hline Triterpenes and steroids & Liebermann - Burchard & + & + & + & - \\
\hline Sesquiterpene lactones & Baljet A and B & + & + & + & + \\
\hline Free amino group & Ninhidrina & - & + & + & + \\
\hline Sugars & Molish & + & + & + & + \\
\hline \multirow{2}{*}{ Reducing sugars } & Benedict & - & + & + & + \\
\hline & Feling $\mathrm{A}$ and $\mathrm{B}$ & - & + & + & + \\
\hline
\end{tabular}

Table 2: Elimination of DPPH radical, ferric ion reduction and total polyphenols of Senecio rhizomatus Rusby extracts.

\begin{tabular}{cccc}
\hline Sample & Elimination of DPPH radical & Reduction of ferric ion $^{+}$ & Total Polyphenols $^{++}$ \\
\hline SeR96 & $150.97^{\mathrm{c}} \pm 10.74$ & $3.07^{\mathrm{d}} \pm 0,25$ & $43.38^{\mathrm{c}} \pm 0.60$ \\
SeR70 & $98.39^{\mathrm{b}} \pm 0.59$ & $81.31^{\mathrm{c}} \pm 0,69$ & $59.92^{\mathrm{a}} \pm 0.40$ \\
SeR50 & $83.55^{\mathrm{b}} \pm 3.51$ & $89.31^{\mathrm{b}} \pm 0,29$ & $76.69^{\mathrm{b}} \pm 0.56$ \\
SeRAc & $93.45^{\mathrm{b}} \pm 1.02$ & $55.77^{\mathrm{a}} \pm 0,88$ & $63.05^{\mathrm{a}} \pm 1.94$ \\
AA & $2.91^{\mathrm{a}} \pm 0.01$ & - & - \\
\hline
\end{tabular}

Table 3. Dose response of Senecio rhizomatus Rusby extracts on the activity of the plasma membrane redox system, malondialdehyde content and glutathione content in erythrocytes subjected to oxidative stress with $\mathrm{H}_{2} \mathrm{O}_{2}$

\begin{tabular}{ccccc}
\hline Sample & Concentration $(\mu \mathrm{g} / \mathrm{mL})$ & $\mathrm{PMRS}^{\sharp}$ & $\mathrm{GSH}(\mu \mathrm{g} / \mathrm{mL})$ & $\mathrm{MDA}(\mathrm{nmol} / \mathrm{mL})$ \\
\cline { 2 - 5 } $\mathrm{H}_{2} \mathrm{O}_{2}$ & - & - & $21.40 \pm 1.10$ & $0.95 \pm 0.03$ \\
Control & - & $3.11 \pm 0.04$ & $34.63^{\mathrm{a}} \pm 0.45$ & $0.11 \pm 0.02$ \\
& 100 & $3.56 \pm 0.14$ & $37.77^{\mathrm{b}} \pm 2.70$ & $0.54^{\mathrm{b}} \pm 0.00$ \\
SeR96 & 50 & $3.40 \pm 0.09$ & $34.70^{\mathrm{a}} \pm 1.75$ & $0.58^{\mathrm{b}} \pm 0.00$ \\
& 25 & $3.25 \pm 0.09$ & $33.03^{\mathrm{a}} \pm 1.01$ & $0.57^{\mathrm{b}} \pm 0.01$ \\
& 12.5 & $3.25 \pm 0.11$ & $33.36^{\mathrm{a}} \pm 1.63$ & $0.80^{\mathrm{b}} \pm 0.01$ \\
\hline & 100 & $3.90^{\mathrm{b}} \pm 0.03$ & $38.05^{\mathrm{b}} \pm 2.36$ & $0.52^{\mathrm{b}} \pm 0.01$ \\
SeR70 & 50 & $3.35 \pm 0.04$ & $36.88^{\mathrm{b}} \pm 2.34$ & $0.52^{\mathrm{b}} \pm 0.00$ \\
& 25 & $3.28 \pm 0.14$ & $35.94^{\mathrm{b}} \pm 2.99$ & $0.56^{\mathrm{b}} \pm 0.01$ \\
& 12.5 & $3.28 \pm 0.10$ & $35.85^{\mathrm{b}} \pm 2.54$ & $0.66^{\mathrm{b}} \pm 0.03$ \\
SeR50 & 100 & $4.59^{\mathrm{b}} \pm 0.07$ & $40.87^{\mathrm{b}} \pm 2.36$ & $0.39^{\mathrm{b}} \pm 0.01$ \\
& 50 & $4.02^{\mathrm{b}} \pm 0.05$ & $39.69^{\mathrm{b}} \pm 2.34$ & $0.42^{\mathrm{b}} \pm 0.01$ \\
& 25 & $3.94^{\mathrm{b}} \pm 0.17$ & $38.76^{\mathrm{b}} \pm 2.99$ & $0.45^{\mathrm{b}} \pm 0.03$ \\
& 12.5 & $3.69^{\mathrm{a}} \pm 0.15$ & $37.72^{\mathrm{b}} \pm 2.07$ & $0.53^{\mathrm{b}} \pm 0.05$ \\
SeRAc & 100 & $3.80 \pm 0.14$ & $34.49^{\mathrm{a}} \pm 2.93$ & $0.55^{\mathrm{b}} \pm 0.01$ \\
& 50 & $3.40 \pm 0.11$ & $34.02^{\mathrm{a}} \pm 1.43$ & $0.56^{\mathrm{b}} \pm 0.01$ \\
& 25 & $3.30 \pm 0.09$ & $33.41^{\mathrm{a}} \pm 2.14$ & $0.61^{\mathrm{b}} \pm 0.03$ \\
& 12.5 & $3.24 \pm 0.07$ & $33.12^{\mathrm{a}} \pm 2.03$ & $0.76^{\mathrm{b}} \pm 0.03$ \\
\hline
\end{tabular}


\#DPPH radical elimination capacity expressed in IC50 ( $\mu \mathrm{g} / \mathrm{mL}) ;+$ Ferric ion reduction expressed in milligrams of ascorbic acid (AA) per each gram of dry extract; ++Polyphenol content expressed in milligrams of gallic acid (GA) per each gram of dry extract. In each column, the average values $(n=3,+E E M)$ with different letters indicate significant difference $(p<0.01)$ based on Tukey's multiple comparison test.

\section{PMRS activity in erythrocyte membranes, MDA and GSH} content.

The SeR70, SeR50 and SeRAc extracts showed an increase in PMRS activity in erythrocyte membranes, which depended on the concentration of the extracts, being the SeR50 extract the one with the highest activity as shown in Figure 4.

Regarding MDA content, all the extracts and concentrations significantly decreased the MDA release $(\mathrm{P}<0.001)$ due to the erythrocytes subjected to oxidative stress compared to the $\mathrm{H}_{2} \mathrm{O}_{2}$ group (Figure 5). Moreover, they maintained high levels of GSH compared to the $\mathrm{H}_{2} \mathrm{O}_{2}$ group as shown in Figure 6 .

\#Redox activity of the Senecio rhizomatus Rusby extracts in the erythrocyte plasma membrane determined in nmol of ferrocyanidin / $\mathrm{mL}$ of PRBC / $30 \mathrm{~min}$. In each column (average $\mathrm{n}=3$, \pm EEM) letter "a" $(\mathrm{p}<0.05)$ and letter "b" $(\mathrm{p}<0.01)$ when compared to the control group for PMRS assay and with the $\mathrm{H}_{2} \mathrm{O}_{2}$ group for MDA and GSH assays.

\section{DISCUSSION}

In the present research, the antioxidant capacity of the SeR96, SeR70, SeR50 and SeRAc extracts of Senecio rhizomatus Rusby was evaluated, as well as their relationship with the polyphenol content, the increase of the activity of the erythrocyte plasma membrane redox system, and the preservation of its integrity in the oxidative stress induced with $\mathrm{H}_{2} \mathrm{O}_{2}$.

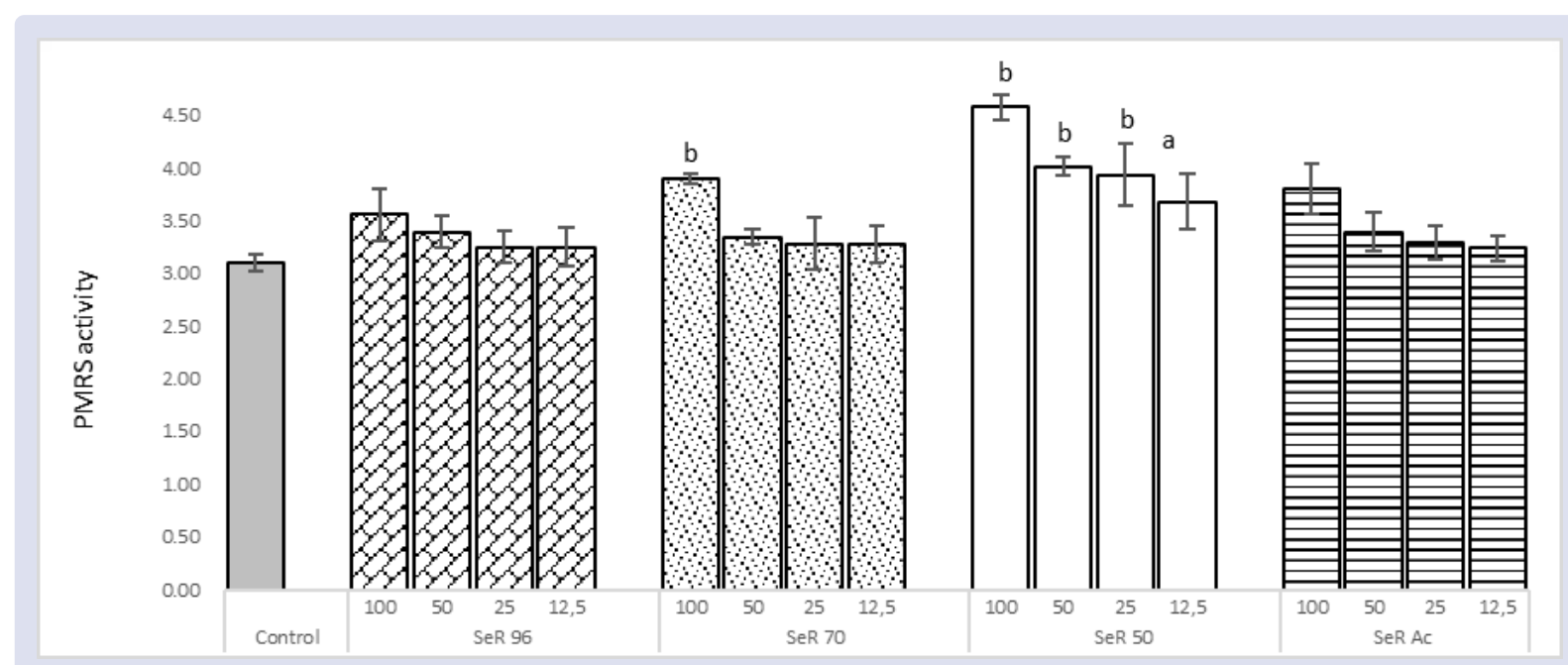

Figure 4: Dose response of SeR96, SeR70, SeR50 and SeRAc extracts compared to erythrocytes PMRS activity, determined in nmol of ferrocyanidin / mL of PRBC / 30 min., where PMRS: Plasma membrane redox system; PRBC: packed red blood cells; a: $p<0.05$ and b: $p$ $<0.01$ compared to the control group.

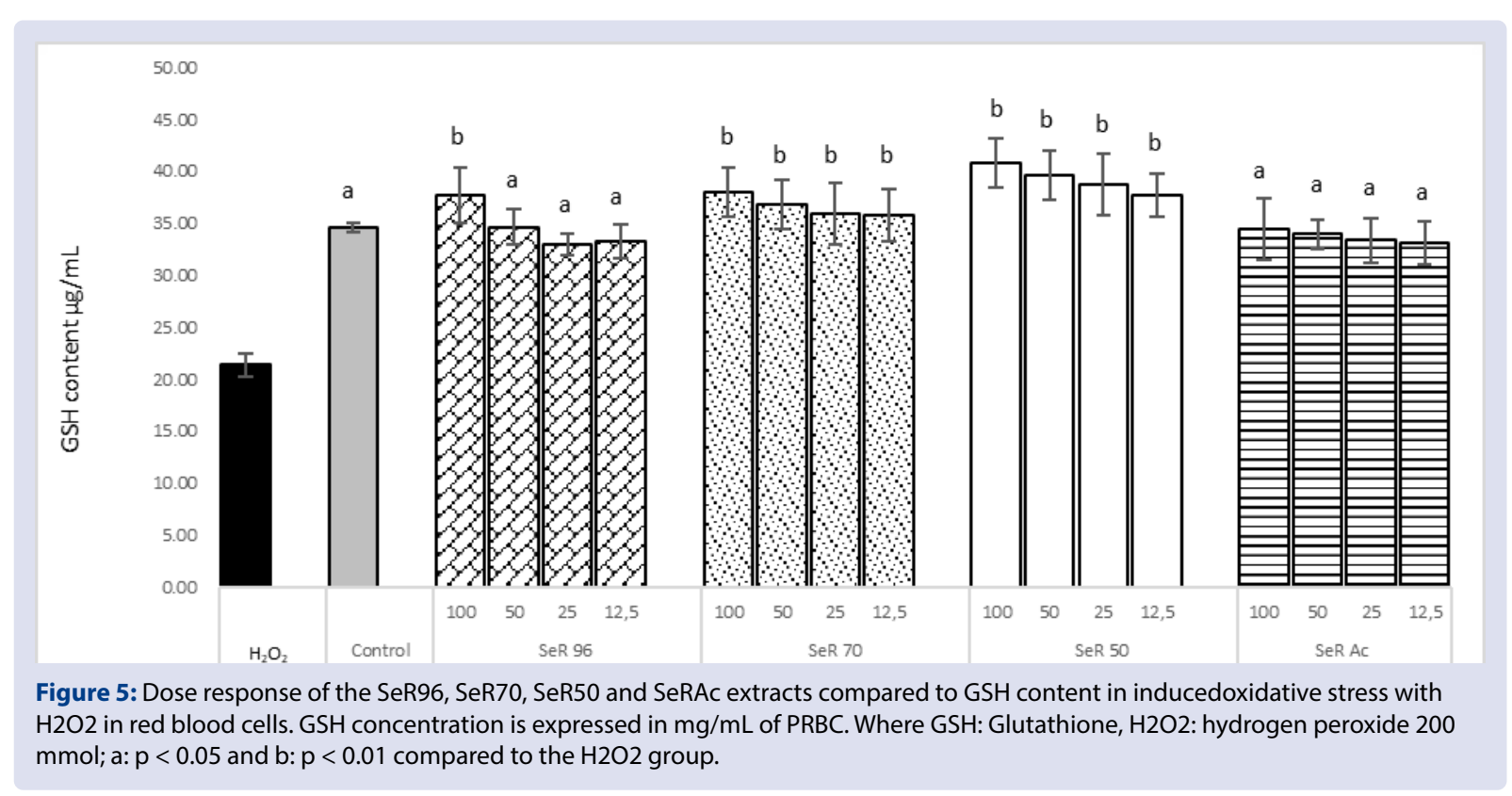




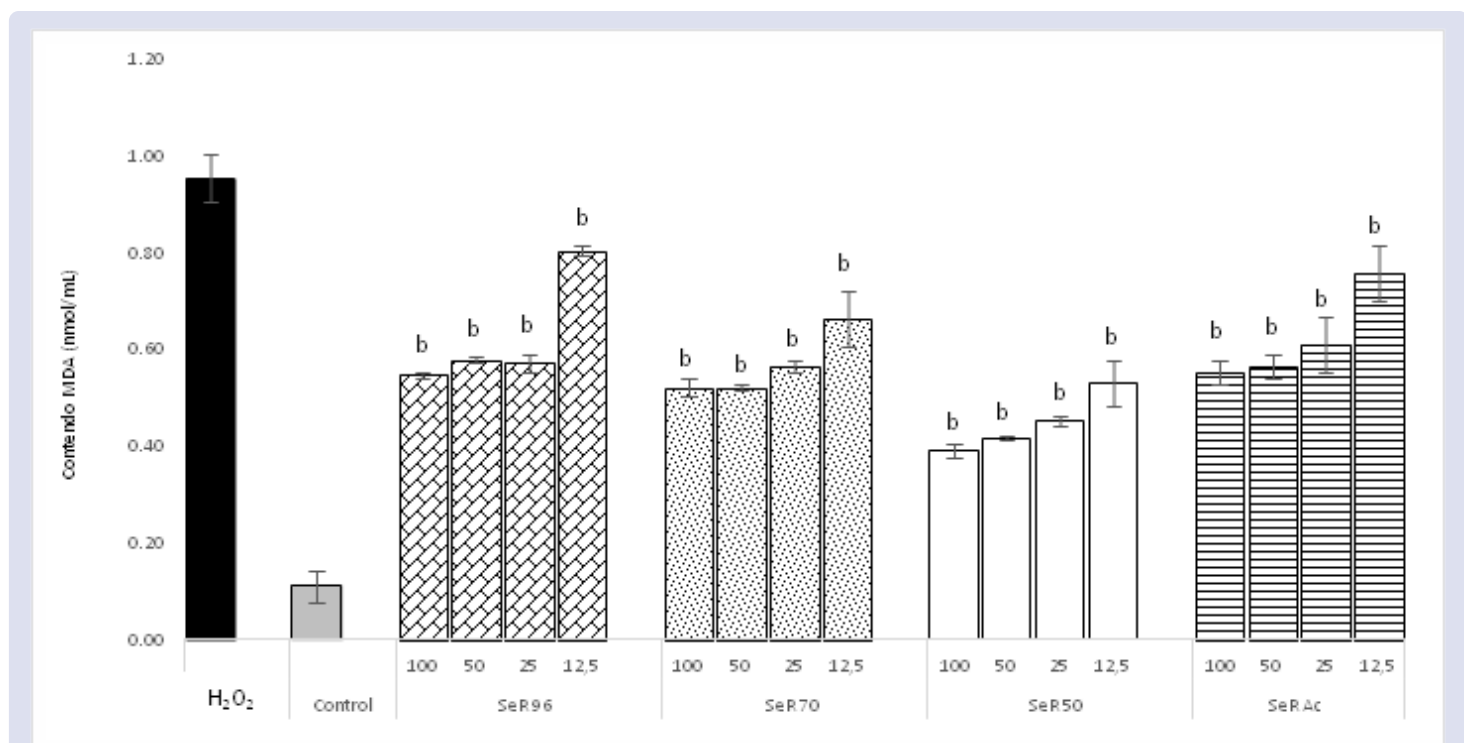

Figure 6: Dose response of the SeR96, SeR70, SeR50 and SeRAc extracts compared to MDA released due to $\mathrm{H}_{2} \mathrm{O}_{2}$-induced stress in red blood cells. MDA concentration is expressed in $\mathrm{nmol} / \mathrm{mL}$ of PRBC. MDA: Malondialdehyde, $\mathrm{H}_{2} \mathrm{O}_{2}$ : hydrogen peroxide $200 \mathrm{mmol}$; $\mathrm{b}: \mathrm{P}<0.01$ compared to the $\mathrm{H}_{2} \mathrm{O}_{2}$ group.

Alkaloids, flavonoids, phenolic compounds, sesquiterpene lactones and sugars were identified in all types of extracts. In SeR70, SeR50 and SeRAc extracts, quinones, tannins, amino groups and reducing sugars were identified. In addition, in SeR96, SeR70 and SeRAc extracts, triterpenes and steroids were also identified (Table 1). The type, performance and quality of secondary metabolites with pharmacological activity are related to factors such as the habitat of the plant species or the polarity of the solvents used in the extraction. ${ }^{21,32}$ The results of this study showed that the increase of the polarity of the solvents increases the variety of the metabolites and the performance of the extracts. The studies on the identification and quantification of secondary metabolites of this species are scarce and this could be due to the complicated access to its habitat since the geographical distribution is between 3500 and 5000 meters above sea level in the Andes of Ecuador, Peru and Bolivia. ${ }^{17,33}$ In addition, the ethnobotanical evidence shows that the population uses it in infusion or as a poultice for treatment of ovarian inflammation, menstrual cramps, respiratory tract infections and external wounds. ${ }^{34}$ In the studies of Puelles et $a l .^{18}$ and Soto ${ }^{19}$, flavonoids, saponins, steroids and alkaloids were also identified in the $96^{\circ}$ ethanolic extract of Senecio rhizomatus. Moreover, polyphenols, flavonoids, tannins, terpenes and pyrrolizidinic alkaloids were identified in the $85^{\circ}$ methanolic fraction in the Senecio Vulgaris species that has the same habitat; these metabolites confer antioxidant, antimicrobial and antifungal activity. ${ }^{35}$ Pyrrolizidine alkaloids have also been identified in Senecio jacobaea and Senecio Brasiliensis species, where their anti-inflammatory, immunomodulatory and cytotoxic effect have been demonstrated. ${ }^{36,37}$ In the case of Senecio nulans, Senecio chiquianensis, Senecio hyoseridifolius, Senecio tphrosiodies, secondary metabolites have been identified in ethanolic extracts and essential oils (terpenes, phenolic compounds, flavonoids, pyrrolizidinic alkaloids, lactones), showing good antibacterial activity against staphylococcus aureus bacteria. ${ }^{38-41}$ It is necessary to explore the characterization of secondary metabolites of Senecio rhizomatus in order to guide in vitro and in vivo pharmacological research that would favor the preservation and rational use of the species.

All the extracts eliminated the DPPH radical dependently on their concentration (Figure 2) and the SeR50, SeR70 and SeRAc extracts had the best IC50 (Table 2). In addition, they reduced the ferric ion, being the SeR50 the one that showed more potency. When evaluating the relationship between the power to eliminate the DPPH radical expressed in IC50 and the power of ferric ion reduction in the extracts, a correlation of $(r=-0.903)$ was evidenced. Regarding the content of polyphenols, SeR50 presented a higher quantity and when evaluating the relationship with the elimination of DPPH and reduction of ferric ion, correlations of $r=-0.899$ and $r=0.885$ were shown respectively. The elimination of the DPPH radical showed the capacity to transfer electrons or donate hydrogens and the ferric ion reduction test showed the redox potential, which allows the stabilization of free radicals in hydrophilic fractions ${ }^{42,43}$, which would avoid the formation of reactive oxygen species $\left(\mathrm{O}_{2}-, \mathrm{H}_{2} \mathrm{O}_{2}, \bullet \mathrm{OH}\right)$, nitrogen $(\mathrm{NO})$ and lipoperoxides that damage diverse cellular structures. ${ }^{6}$ The correlation between DPPH and FRAP assays with the content of polyphenols shows that the antioxidant power is mainly due to the presence of compounds of hydrophilic nature such as polyphenols, phenolic acids, flavonoids, tannins, alkaloids. The antioxidant potential of several medicinal plants has been attributed to the oxidizing and reducing power of phenolic compounds acting as oxygen sensors, electron donors and as reducers. ${ }^{44,45}$

The Senecio species are cosmopolitan; in Peru there are about 97, some of them already evaluated, that have shown antibacterial effects. ${ }^{46}$ The $96^{\circ}$ ethanolic extract of Senecio rhrizomatus is effective against the growth of Staphylococcus aureus. ${ }^{19}$ However, the antioxidant capacity and polyphenol content has not yet been determined. In other endemic species of Europe, such as Senecio racemosus and Senecio nemorensis, total polyphenols ( 139.43 and $136.05 \mathrm{mg} \mathrm{GAE} / \mathrm{g}$ ) have been determined and the elimination of DPPH radical expressed in IC50 (24.40 and $18.81 \mu \mathrm{g} / \mathrm{mL}$ ) presented correlation of $-0.987,{ }^{47}$ demonstrating that the antioxidant potential is due to the presence of phenolic compounds. Also, $5 \mathrm{mg} \mathrm{GAE} / \mathrm{g}$ of polyphenols as well as the antioxidant capacity expressed in IC50 of DPPH $(12.1 \mu \mathrm{g} / \mathrm{mL})$ were determined in the 50 methanolic extract of Senecio longiflorus, demonstrating correlation between polyphenols and antioxidant capacity and the antimicrobial activity with a lower cytotoxic activity in mammalian cells. ${ }^{45}$ In the present study, it was demonstrated that the antioxidant capacity of the hydrophilic fraction is related to the content of polyphenols, however, it is also necessary to evaluate the relationship with the content of alkaloids as well as to evaluate the antioxidant power in lipophilic fractions. 
The maintenance of PMRS activity in eukaryotic cells allows protection against external free radicals by transferring electrons from the intracellular space to the extracellular space in a system involving antioxidant enzymes, reduced substrates and low molecular weight substances. ${ }^{10,48}$ In the present investigation, all the types of extracts increased PMRS activity dependently on the concentration; however, only the SeR50 (all concentrations) and SeR70 $(100 \mu \mathrm{g} / \mathrm{mL}$ concentration) were observed to be significantly different from the control group (Figure 4). These results are consistent with the increase in GSH content where all extract concentrations are significantly different from the $\mathrm{H}_{2} \mathrm{O}_{2}$ group (Figure 5). Finally, the MDA content released in the erythrocyte membrane as a result of the lipoperoxidation of the membrane phospholipids decreased significantly with the treatment of all the extracts compared to the $\mathrm{H}_{2} \mathrm{O}_{2}$ group (Figure 6). Flavonoids, phenolic acids and vitamins from plant species improve the reduction capacity of the erythrocyte membrane against the aggression of free radicals, restoring fluidity and stability ${ }^{49-51}$ Polyphenols form an inactive redox complex with iron, protecting the erythrocyte membrane from lipid peroxidation, ${ }^{52}$ and in silico studies it has been demonstrated that they act as cofactors of the cytochrome b5 reductase enzyme, favoring the stability of PMRS. ${ }^{13,20}$ This explains that the capacity to reduce ferric ion of the polyphenols of the Senecio rhizomatus demonstrated in this study is reflected in the affinity on the iron of hemoglobin. Thus, it is able to form reduced stable compounds, increasing the activity of the PMRS of erythrocytes; however, it is still necessary to identify the type and structure of the main polyphenols of this species to know the mechanisms by which it increases the activity of the PMRS.

The stability of PMRS in erythrocytes maintains the necessary amount of ascorbate to face reactive oxygen species (ROS). ${ }^{53}$ For this, there is a recycling mechanism where, after being oxidized to dehydroascobate, at an intracellular level, the hydrophilic antioxidant GSH reduces it again to ascorbate. Furthermore, it protects the integrity of the intracellular alpha tocopherol, which has the function of attenuating the lipoperoxidation; in this way, the GSH mediates the redox changes regulating the physiological function of the erythrocyte. ${ }^{54,55}$ In this research, it was observed that erythrocytes treated with the extracts maintained the content of GSH equivalent to the control group when exposed to oxidative stress and it did not decrease significantly as it happened with the $\mathrm{H}_{2} \mathrm{O}_{2}$ group (without treatment). This finding shows that polyphenols, due to their demonstrated antioxidant capacity, would maintain the amount of ascorbate and, in the same way, the system would maintain its stable recycling protecting the membrane of erythrocytes from the fenton reaction due to the $\mathrm{H}_{2} \mathrm{O}_{2}$ action on the hemoglobin's iron.

The erythrocyte membrane has a high content of saturated fats and is, hence, exposed to lipoperoxidation, which makes it even more vulnerable due to the presence of iron, which produces the hydroxyl radical $(\bullet \mathrm{OH})$. Also, this damages the cellular components, ${ }^{56}$ reducing cell fluidity, compromising the deformation of the cell, and disturbing the oxygen supply to the tissues, producing hemolysis. ${ }^{57}$ The increase of the GSH concentration in the erythrocyte membrane after the treatment with the extracts allows us to hypothesize that the metabolites would be strengthening the ascorbate recycling, the protection of the intracellular alpha tocopherol, preventing the reactive oxygen species from generating and avoiding lipoperoxidation. That is why a decrease of the DMA concentration is observed in the treatment groups compared to the $\mathrm{H}_{2} \mathrm{O}_{2}$ group.

\section{CONCLUSION}

The antioxidant capacity of hydroalcoholic extracts $\left(96^{\circ}, 70^{\circ}, 50^{\circ}\right)$ and aqueous infusion of Senecio rhizomatus Rusy is related to the content of polyphenols. They increase the activity of the plasma membrane redox system of rat erythrocytes and protect them from oxidative stress induced by $\mathrm{H}_{2} \mathrm{O}_{2}$, showing an increase in the concentration of reduced glutathione and a decrease in malondialdehyde.

\section{ACKNOWLEDGEMENT}

The authors thanks to Norbert Wiener University for financial support.

\section{CONFLICTS OF INTEREST}

The authors declare that they have no conflicts of interest.

\section{REFERENCES}

1. Sies H. Oxidative Stress: Introductory Remarks. In: Oxidative Stress. 1985. p. 1-8

2. Wei-Wei, Qiuju-Liu, Yi-Tan, Lucheng-Liu, Xiaokun-Li, Lu-Cai. OXIDATIVE STRESS, DIABETES, AND DIABETIC COMPLICATIONS Hemoglobin. 2009;33(5):370-6.

3. Rizvi SI, Pandey KB. Activation of the erythrocyte plasma membrane redox system by resveratrol: A possible mechanism for antioxidant properties. Pharmacol Reports. 2010;62(4):726-32

4. Higashi $Y$, Maruhashi T, Noma K, Kihara Y. Oxidative stress and endothelial dysfunction: Clinical evidence and therapeutic implications. Trends Cardiovasc Med. 2014;24(4):165-9.

5. Knight JA. Free radicals: Their history and current status in aging and disease. Ann Clin Lab Sci. 1998;28(6):331-46.

6. Toyokuni S. Reactive oxygen species-induced molecular damage and its application in pathology. Phathology Int. 1999;49:91-102

7. Ghezzi P, Jaquet $V$, Marcucci F, Schmidt HHHW. The oxidative stress theory of disease: levels of evidence and epistemological aspects. $\mathrm{Br}$ J Pharmacol. 2017;174(12):1784-96.

8. Calderon J, Burgos E, Perez C, Lopez L. A Review on the Dietary Flavonoid Kaempferol. Mini Rev Med Chem. 2011;11(4):298-344.

9. Fang Y-Z, Yang S, Wu G. Free Radicals, Antioxidants, and Nutrition. Regul Physiol Syst by Nutr. 2002;18:872-9

10. Rizvi S, Srivastava N. Erythrocyte plasma membrane redox system in first degree relatives of type 2 diabetic patients. Int $\mathrm{J}$ Diabetes Mellit. 2010.

11. Rizvi SI, Jha R, Maurya PK. Erythrocyte Plasma Membrane Redox System in Human Aging. Rejuvenation Res. 2006;9(4):470-4.

12. Rizvi SI, Srivastava N. Erythrocyte plasma membrane redox system in first degree relatives of type 2 diabetic patients. Int $\mathrm{J}$ Diabetes Mellit. 2010;2(2):119-21.

13. Fatima M, Kesharwani RK, Misra K, Rizvi SI. Protective effect of theaflavin on erythrocytes subjected to in vitro oxidative stress. Biochem Res Int [Internet]. 2013 [cited 2018 Oct 2];2013:649759. Available from: http://www.ncbi.nlm.nih.gov/pubmed/24455262

14. Vinod J, Mutum PD. Resveratrol: Importance, role, contents in wine and factors influencing its production. Proc Natl Acad Sci India Sect B - Biol Sci. 2009;79:212-26.

15. Tan BL, Norhaizan ME, Liew WPP, Rahman HS. Antioxidant and oxidative stress: A mutual interplay in age-related diseases. Front Pharmacol. 2018;9(1162):1-28

16. Beltrán H. Las Asteráceas (Compositae) del distrito de Laraos (Yauyos, Lima, Perú). Rev Peru Biol. 2016;23(2):195-220.

17. Beltrán H, Gamarra JR. The genus Senecio L. (AsteraceaeSenecioneae) from departamento of Lima, Peru. Arnaldoa. 2015;22(2):395-412.

18. Puelles M, Galarza V, Gabriel J, Moris G. Las plantas medicinales de Perú [Internet]. Catarata. 2010. 1-144 p. Available from: http://www. reduniversitaria.es/ficheros/Plantas medicinales. LIBRO.pdf

19. Soto MY. Determinación del efecto antimicrobiano in vitro de un gel elaborado con extracto etanólico de hojas de Senecio rhizomatus Rusby (Asteraceae) [Internet]. Universidad Nacional Mayor de San Marcos; 2015 [cited 2018 Feb 20]. Available from: http:// cybertesis.unmsm.edu.pe/bitstream/handle/cybertesis/4628/Soto_ $\mathrm{mm}$.pdf? sequence $=1$ \&isAllowed $=y$ 
20. Singh P, Kesharwani RK, Misra K, Rizvi SI. Modulation of Erythrocyte Plasma Membrane Redox System Activity by Curcumin. Biochem Res Int. 2016;2016.

21. Casado R, Landa A, Calvo J, García-Mina JM, Marston A, Hostettmann $\mathrm{K}$, et al. Anti-inflammatory, antioxidant and antifungal activity of Chuquiraga spinosa. Pharm Biol. 2011;49(6):620-6.

22. Lock O. Investigación Fitoquímica. Métodos en el estudio de productos naturales. 3ra ed. Lima: PUCP; 2016.

23. Quispe-Mendoza L, Betalleluz-Pallardel I, Vargas-Delgado L, Velezmoro-Sánchez C. Stability of cooked pressed yellow potato (Solanum goniocalyx) in frozen storage. Sci Agropecu. 2018;9(1):11321.

24. Umamaheswari $M$, Chatterjee T. In vitro antioxidad activities of the fractions of coccinia grandis L. Leaf Extract. Afr J Tradit. 2008;5(1):6173.

25. Benzie IFF, Strain JJ. The ferric reducing ability of plasma (FRAP) as a measure of "antioxidant power": The FRAP assay. Anal Biochem. 1996;239(1):70-6.

26. National Research Council. GUIDE FOR THE CARE AND USE OF LABORATORY ANIMALS (Eighth Edition). 2011.

27. Avron M, Shavit N. A sensitive and simple method for determination of ferrocyanide. Anal Biochem. 1963

28. Stocks J, Dormandy TL. The Autoxidation of Human Red Cell Lipids Induced by Hydrogen Peroxide. Br J Haematol. 1971;20(1):95-111.

29. Esteraauer H, Cheeseman KH. Determination of Aldehydic Lipid Peroxidation Products: Malonaldehyde and 4-Hydroxynonenal. Methods Enzymol. 1990;186:407-21.

30. Sedlak J, Lindsay RH. Estimation of total, protein-bound, and nonprotein sulfhydryl groups in tissue with Ellman's reagent. Anal Biochem. 1968;25(C):192-205

31. Beutler E. Red Cell Meatabolism A Manual of Biochemical Methods. thrid edti. Grune \& Stratton I, editor. 1984.

32. Rocío D, Carreño V. El orégano de monte (Lippia origanoides) de Alto Patía: Efecto del método de obtención de sus extractos sobre la composición y la actividad antioxidante de los mismos. 2012.

33. Salomón L, Sklenár P, Freire S. Synopsis of Senecio series Culcitium (Asteraceae: Senecioneae, Senecioninae) in the Andean region of South America. Phytotaxa. 2018;340(1):1-47.

34. Tello-Ceron G, Flores Pimentel M, Gómez Galarza V. USO DE LAS PLANTAS MEDICINALES DEL DISTRITO DE QUERO, JAUJA, REGIÓN JUNÍN, PERÚ. Ecol Apl. 2019;18(1):11.

35. Hamid HK, Kadhim EJ. Extraction, isolation and characterization of Pyrrolizidine Alkaloids present in Senecio vulgaris Linn grown in Iraq. J Pharmacogn Phytochem Fig. 2016;5(6):28-37.

36. Kopp T, Salzer L, Abdel-Tawab M, Mizaikoff B. Efficient extraction of pyrrolizidine alkaloids from plants by pressurised liquid extraction- $\mathrm{A}$ preliminary study. Planta Med. 2020;86(1):85-90

37. Toma W, Trigo JR, De Paula ACB, Brito ARMS. Preventive activity of pyrrolizidine alkaloids from Senecio brasiliensis (Asteraceae) on gastric and duodenal induced ulcer on mice and rats. J Ethnopharmacol. 2004;95(2-3):345-51.

38. Mitsui T, Hayashi Kl, Kawai M, Kido M, Tani H, Takaoka D, et al. Culcitiolides E-J, six new eremophilane-type sesquiterpene derivatives from senecio culcitioides. Chem Pharm Bull. 2013;61(8):816-22.

39. Vega BA, Noemi L, Chóquez BG, Maribel F. "EVALUACIÓN DE LA ACTIVIDAD ANTIMICROBIANA in vitro DEL EXTRACTO ETANÓLICO DE LAS HOJAS DE Senecio hyoseridifolius Wedd (Llancahuasha) FRENTE A CEPAS DE Escherichia coli, Staphylococcus aureus, Staphylococcus epidermidis y Pseudomonas aeruginosa. Universidad Inca Garcilazo de la Vega; 2019.
40. Alderete Espejo H. Actividad antimicrobiana, antioxidante in vitro y determinación de la composición química de tres aceites esenciales del género Senecio del Perú. Universidad Nacional Mayor de San Marcos; 2017

41. Blanco-olano C, Olascuaga-castillo K, Valdiviezo-campos JE, Blancoolano C, Olascuaga-castillo K, Rubio-guevara S, et al. Senecio tephrosioides Turcz. (Asteraceae): Una revisión de etnobotánica, fitoquímica y farmacología. Ethnobot Res Appl. 2020;19(14).

42. Kedare SB, Singh RP. Genesis and development of DPPH method of antioxidant assay. J Food Sci Technol. 2011;48(4):412-22.

43. Xu DP, LiY, Meng X, ZhouT, ZhouY, Zheng J, et al. Natural antioxidants in foods and medicinal plants: Extraction, assessment and resources. Vol. 18, International Journal of Molecular Sciences. MDPI AG; 2017.

44. Lukmanul Hakkim F, Gowri Shankar C, Girija S. Chemical composition and antioxidant property of holy basil (Ocimum sanctum L.) leaves, stems, and inflorescence and their in vitro callus cultures. J Agric Food Chem. 2007;55(22):9109-17.

45. Asong JA, Amoo SO, McGaw LJ, Nkadimeng SM, Aremu AO, Otang Mbeng W. Antimicrobial activity, antioxidant potential, cytotoxicity and phytochemical profiling of four plants locally used against skin diseases. Plants. 2019;8(9)

46. Beltrán H, Roque J. El género Senecio L. (Asteraceae-Senecioneae) en el departamento de Lima, Perú. Arnaldoa [Internet]. 2015;22(2):395412. Available from: http://journal.upao.edu.pe/Arnaldoa/article/ view/208\%0Ahttp://files/2751/Beltrán y Gamarra - 2015 - EL GENERO SENECIO L. (ASTERACEAE-SENECIONEAE) EN E.pdf\%OAhttp:// files/2752/208.html

47. ALBAYRAK S, AKSOY A, YURTSEVEN L, YASSAR A. A Comparative Study on Antioxidant and Antibacterial Activities of Four Senecio Species From Turkey. Int J Second Metab. 2016;2(2):26-36.

48. Kennett EC, Kuchel PW. Redox Reactions and Electron Transfer Across the Red Cell Membrane. IUBMB Life. 2003:55(7):375-85.

49. Arbos KA, Claro LM, Borges L, Santos CAM, Weffort-Santos AM. Human erythrocytes as a system for evaluating the antioxidant capacity of vegetable extracts. Nutr Res. 2008;28(7):457-63.

50. Claro LM, Soares Leonart MS, Comar SR, Do Nascimento AJ. Effect of vitamins $\mathrm{C}$ and $\mathrm{E}$ on oxidative processes in human erythrocytes Cell Biochem Funct. 2006;24(6):531-5.

51. Saffari $Y$, Sadrzadeh SMH. Green tea metabolite EGCG protects membranes against oxidative damage in vitro. Life Sci. 2004;74(12):1513-8.

52. Grinberg LN, Newmark H, Kitrossky N, Rahamim E, Chevion M Rachmilewitz EA. Protective effects of tea polyphenols against oxidative damage to red blood cells. Biochem Pharmacol. 1997;54(9):973-8.

53. Mendiratta S, Qu ZC, May JM. Erythrocyte defenses against hydrogen peroxide: The role of ascorbic acid. Biochim Biophys Acta Gen Subj. 1998;1380(3):389-95

54. Mendiratta S, Qu ZC, May JM. Erythrocyte ascorbate recycling Antioxidant effects in blood. Free Radic Biol Med. 1998;24(5):789-97.

55. Pandey KB, Rizvi SI. Markers of oxidative stress in erythrocytes and plasma during aging in humans. Oxid Med Cell Longev. 2010;3(1):2-12

56. Pawlak W, Kedziora J, Zolynski K, Kedziora-Kornatowska K Blaszczyk J, Witkowski P, et al. Effect of long term bed rest in men on enzymatic antioxidative defence and lipid peroxidation in erythrocytes. J gravitational Physiol a J Int Soc Gravitational Physiol. 1998 Jul;5(1):P163-4.

57. Rodríguez J, Di Pierro D, Gioia M, Monaco S, Delgado R, Coletta M, et al. Effects of a natural extract from Mangifera indica $L$, and its active compound, mangiferin, on energy state and lipid peroxidation of red blood cells. Biochim Biophys Acta - Gen Subj. 2006;1760(9):1333-42. 


\section{GRAPHICAL ABSTRACT}

\section{Senecio Rhizomatus Rusby}

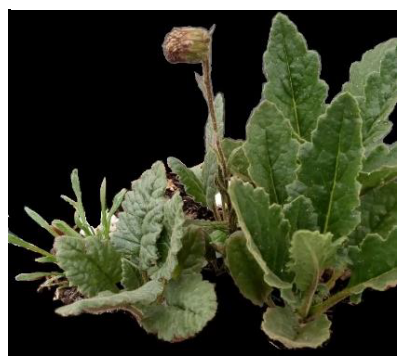

$\underline{\text { Identification of metabolites }}$

\begin{tabular}{|l|}
\hline - Alkaloids \\
- Flavonoids \\
- Phenolic compounds \\
- Sesquiterpene lactones \\
- Sugars \\
\hline
\end{tabular}

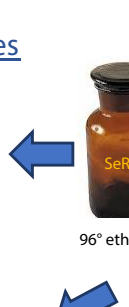

Obtaining extracts
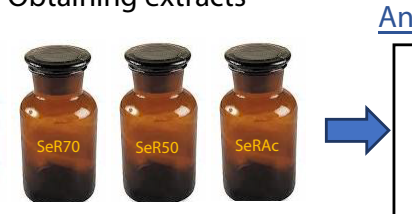

Antioxidant capacity

FRAP

$\mathrm{DPPH}$

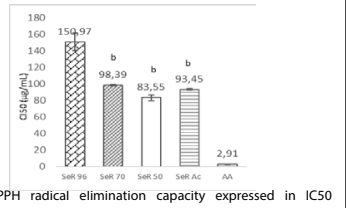

$\mathrm{g} / \mathrm{mL}$ )

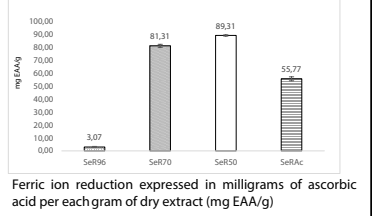

Polyphenols content

Effect on erythrocytes PMRS activity Protective effect on erythrocytes subjected to oxidative stress

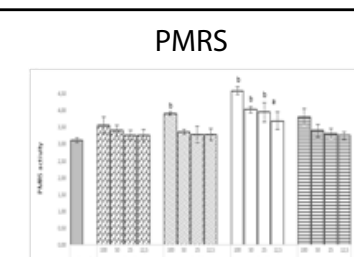

SeR96, SeR70, SeR50 and SeRAc compared to enthrocytes PMRS activity a: $\mathrm{P}<0.05$ and $\mathrm{b}: \mathrm{p}<$ 0.01 compared to the control group
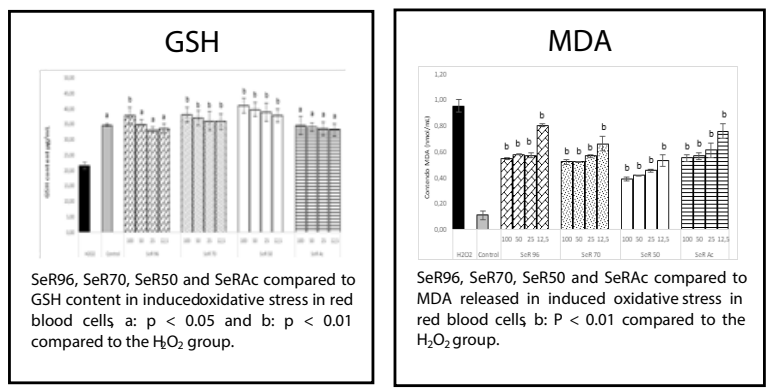
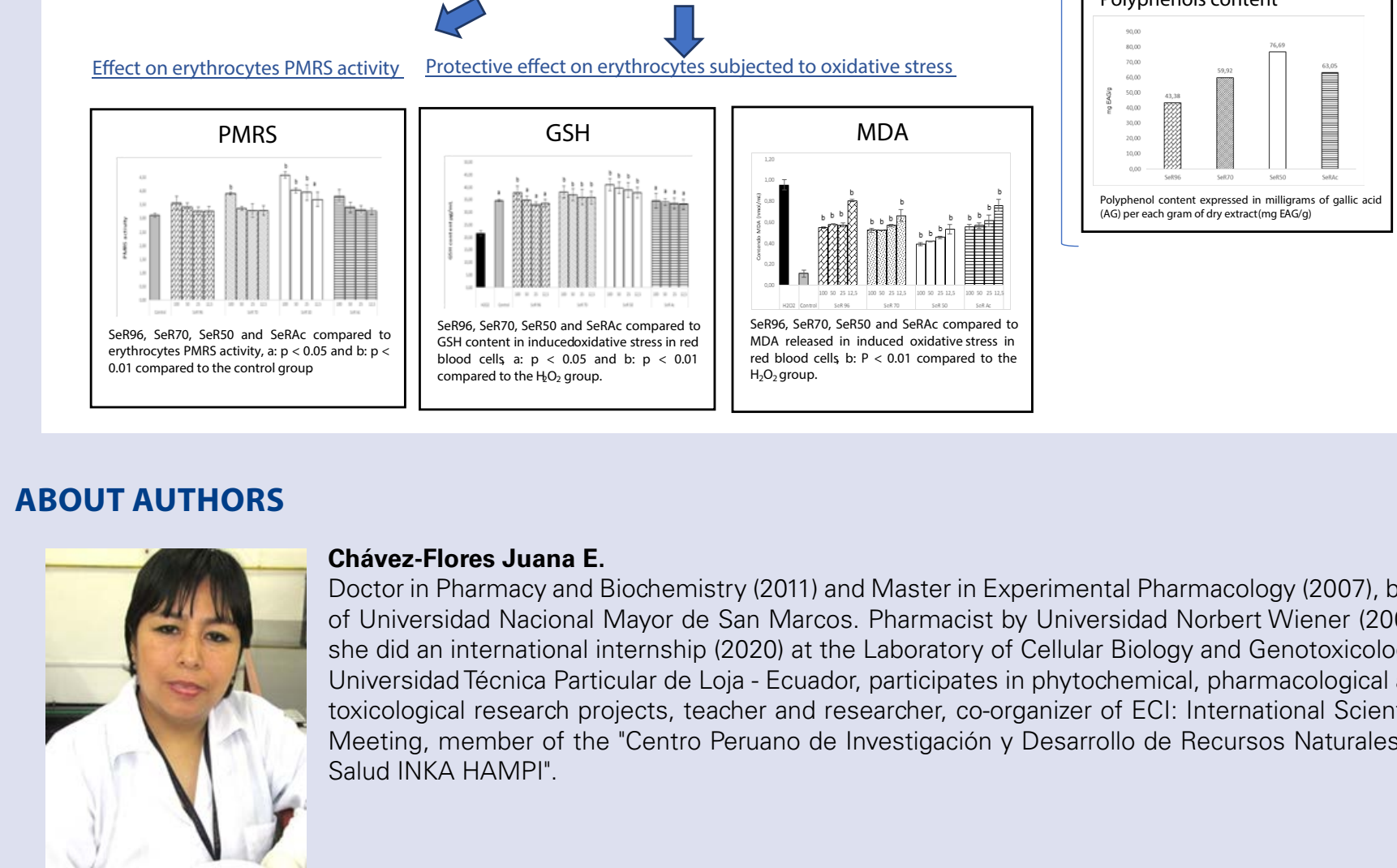

Chávez-Flores Juana E.

Doctor in Pharmacy and Biochemistry (2011) and Master in Experimental Pharmacology (2007), both of Universidad Nacional Mayor de San Marcos. Pharmacist by Universidad Norbert Wiener (2004), she did an international internship (2020) at the Laboratory of Cellular Biology and Genotoxicology Universidad Técnica Particular de Loja - Ecuador, participates in phytochemical, pharmacological and toxicological research projects, teacher and researcher, co-organizer of ECl: International Scientific Meeting, member of the "Centro Peruano de Investigación y Desarrollo de Recursos Naturales en Salud INKA HAMPI".

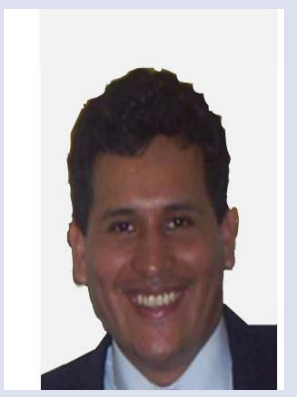

\section{Cárdenas-Orihuela Robert Armando.}

$\mathrm{He}$ is a professor and researcher in the Faculty of Pharmacy, Universidad Norbert Wiener, Lima, Peru. His experience in phytochemical research of natural products with diverse pharmacological and toxicological properties. 

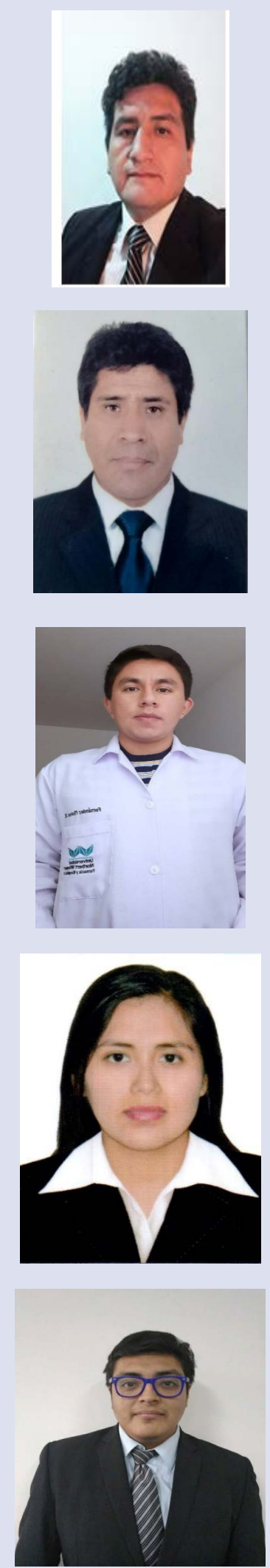

\section{Ramos-Jaco Antonio Guillermo.}

$\mathrm{He}$ is a professor and researcher in the Faculty of Pharmacy, Universidad Norbert Wiener, Lima, Perú. His experience is the products with toxicological and anti-inflammatory properties and the use of animal models to discover new drugs related to toxicological and inflammatory pathologies.

\section{Ñañez-del-Pino Daniel.}

$\mathrm{He}$ is a professor and researcher in the Faculty of Pharmacy, Universidad Norbert Wiener, Lima, Peru. His experience in phytochemical research of natural products with diverse pharmacological and toxicological properties.

\section{Fernández-Flores Nélber.}

Student of Pharmacy and Biochemistry at Universidad Norbert Wiener. He is part of merit school for being awarded the "Alcibiades Horna Figueroa" scholarship. Researcher at Centro de Investigación Farmacéutica of the same university, Asociación Peruana de Estudiantes de Farmacia y Bioquímica (APEFYB). He has been part of the research seedbed group since 2017. He participated as an assistant and speaker at Congreso Nacional Peruano de Estudiantes de Farmacia y Bioquímica (CONAPEFYB), scientific meetings and institutional symposiums obtaining different recognitions. $\mathrm{He}$ is currently practicing in pharmaceutical care.

\section{Rojas-Cardenas Nathalie Felicita.}

She has been part of the research seedbed group of Universidad Norbert Wiener since 2017. Researcher at the Pharmaceutical Research Center of the same university. She participated as an assistant and speaker at Congreso Nacional Peruano de Estudiantes de Farmacia y Bioquímica (CONAPEFYB), scientific meetings and institutional symposia obtaining different recognitions. She currently works in pharmaceutical industry.

\section{Vasquez-Quispe Ángel David.}

He has been part of the research seedbed group of Universidad Norbert Wiener since 2017. Researcher at the Pharmaceutical Research Center of the same university. He participated as an assistant and speaker at Congreso Nacional Peruano de Estudiantes de Farmacia y Bioquímica (CONAPEFYB), scientific meetings and institutional symposia obtaining different recognitions. He currently works as a clinical pharmacy assistant. 


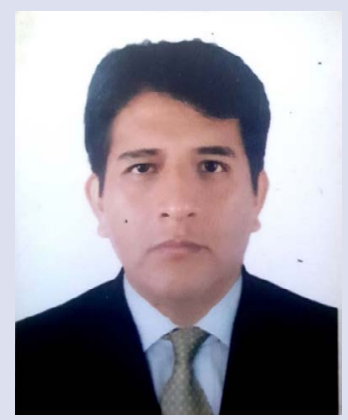

\section{Justil-Guerrero Hugo Jesús.}

$\mathrm{He}$ is a professor and researcher in the Faculty of Pharmacy, Universidad Norbert Wiener, Lima, Peru. His expertise is the design and execution of experimental research for the evaluation of products with effects on anti-inflammatory processes through the use of in vitro and in vivo models with experimental animals.

Cite this article: Justil-Guerrero Hugo J, Chávez-Flores Juana E, Cárdenas-Orihuela Robert A, Ramos-Jaco Antonio G, Nañez-delPino Daniel, Vásquez-Quispe Ángel D, et al. Antioxidant Capacity and Protective Effect of Aqueous and Hydroalcoholic Extracts of Senecio rhizomatus Rusby "Llancahuasi" on Erythrocytes Subjected to Oxidative Stress. Pharmacog J. 2021;13(2): 516-27. 